\title{
USING INTERNATIONAL AND FOREIGN HUMAN RIGHTS LAW IN PUBLIC INTEREST ADVOCACY
}

\author{
Florence Wagman Roisman*
}

\author{
Presented to the Opening Plenary Session of the \\ 2006 National Legal Aid \& Defender Association \\ Litigation and Advocacy Directors Conference \\ Snowbird, Utah \\ June 4, 2006
}

It is a joy and a privilege for me to be here with you all - friends and colleagues of very long standing and new (dare I say "younger"?) colleagues with whom I look forward to forming lifelong friendships.

"*[Much of the depressing material that we have been discussing has to do not with substance, but with procedure - who can gain access to the courts or legislatures, what statutory or regulatory language will be held to be enforceable at the instance of private plaintiffs, etc. ${ }^{* * *}$ Although this is not what I am going to discuss, I do want to underscore that access to the courts and legislatures is crucial. I never understand why so-called conservatives want to keep people out of these institutions, for when aggrieved people do not have such access, they are more likely to express their grievances in other ways, often including violence. $\left.{ }^{1}\right]$

I want to focus on the substance of our work and to talk about how I think

* Florence Wagman Roisman is the William F. Harvey Professor of Law at Indiana University School of Law - Indianapolis. She is very grateful to Professors Connie de la Vega and George Edwards for reading an earlier draft of this speech and making helpful suggestions. She also thanks librarian Richard Humphrey, faculty assistant Mary R. Deer, and research assistant Steven J. LeClere for their invaluable assistance.

** Bracketed material was in the speech prepared for delivery but omitted in the actual presentation in order to keep within the time limit for the session.

*** This refers to the preceding presentation by Marianne Engleman Lado, Esq.

1. As Nadine Gordimer, Nobel Laureate, wrote in reflecting on the fiftieth anniversary of the Universal Declaration of Human Rights,

[w] hen people are deprived over years of any recourse to the provisions of civil society as a means of seeking redress for their material and spiritual deprivations, they lose the faculty of using the law when, at last, such recourse is open to them. The result of this conditioning now is fashionably called 'the culture of violence' $\ldots$

Nadine Gordimer, Foreword to The UnIVERSAL DeCLARATION Of Human Rights: FifTY YeARS AND BEYOND viii (Yael Danieli, Else Stamatopoulou, \& Clarence J. Dias, eds., 1999) (emphasis in original) [hereinafter UDHR: FIFTY YEARS AND BEYOND]. 
we ought to be developing that substance. In doing so, I will expand today upon a theme I sounded at the Litigation and Advocacy Directors Conference here in Snowbird in $2002 .^{2}$ I hope you will read that speech and a pertinent article of mine, called The Lawyer as Abolitionist. ${ }^{3}$ The speech is on [the National Legal Aid and Defender's Association]'s webpage and on my [Indiana University] webpage. I will put this speech and links or citations to several articles and books relevant to what I am about to say on the NLADA webpage ${ }^{4}$ and on my IU webpage. ${ }^{5}$

The theme I want to develop is this: legal services and legal aid are part of a movement that has both depth and breadth. The depth is historical - legal services grew out of twentieth century anti-poverty and civil rights advocacy (which was called human rights advocacy) and nineteenth century anti-slavery and women's rights campaigns - all of this is part of the great movement for human rights, which has ancient roots. The breadth incorporates the modern spectrum of human rights protections - for people of color; women; children; language minorities; people with disabilities; people who are gay, lesbian, bisexual, or transgendered; people who are poor; immigrants; refugees; displacees. The breadth is not only national, but international; indeed, universal.

Since the middle of the twentieth century, this doctrine of human rights has been codified in a set of international documents. 6 Human rights have been codified also in the constitutions of other countries (such as South Africa) 7 and regional organizations (such as the Council of Europe's European Convention on Human Rights). 8 The range of protection is vast: international and foreign human rights law protects civil, political, economic, social, and cultural rights. Its prohibitions of discrimination are broader than those expressed in domestic U.S. law.

I am here to urge that in all of our work we ought to be using the standards of international and foreign human rights law. I think that we ought

2. Florence Wagman Roisman, Keynote Address to the 2002 NLADA Litigation and Advocacy Directors Conference, Snowbird, Utah: Aggressive Advocacy, June 23, 2002, available at http://www.nlada.org/DMS/Documents/1028824673.77/document_info; http://www.indylaw.indiana.edu/instructors/roisman/.

3. Florence Wagman Roisman, The Lawyer as Abolitionist: Ending Homelessness and Poverty in Our Time, 19 ST. LouIS U. PUB. L. REv. 237 (2000), reprinted in REPRESENTING THE POOR AND Homeless: INNOVATIONS IN ADVOCACY 21 (Sidney D. Watson, ed., 2001).

4. See infra, Recommended Reading.

5. Id.

6. A.W. BRIAN SIMPSON, Human RIGHTS AND THE END OF EMPIRE: BRITAIN AND THE GENESIS OF THE EUROPEAN CONVENTION (2001) ("[T]he movement for the international protection of human rights is largely a product of the Second World War and its immediate aftermath.").

7. S. Afr. Const. $1996 \quad \& \quad 184$, available at http://www.info.gov.za/documents/constitution/index.htm.

8. European Convention on Human Rights, Nov. 4, 1950 - Jan. 20, 1966, available at http://www.hri.org/docs/ECHR50.html. 
to be doing this in all forums - in federal and state courts, in Congress and in state legislatures and city councils, in the media, and in every venue in which we contribute to public education - giving speeches, writing letters to the editor and op-ed pieces, participating in blogs, and talking to our families and friends. Whatever we are doing, whatever issues we are addressing, whatever arguments we are making, whatever forums we are employing, we always ought consciously to add a human rights component.

Now, you might be inclined to react to this by thinking that I have gone off the deep end - that it was bad enough that I thought that we could end poverty and homelessness in our time, ${ }^{9}$ but it is ridiculous to think that we can do that by importing into domestic jurisprudence and common discourse the standards of international and foreign human rights law. I hope to persuade you that this is not ridiculous - that it is the logical next step in the program that started with validating the full humanity and citizenship of people of color and of women. Please remember that much that seemed ridiculous a hundred years ago is completely accepted now.

One hundred years ago, in the United States, women could not vote. One hundred years ago, in most of the United States, African-Americans could not vote, either - prevented not by laws but by widespread, governmental and private violations of laws and the use of such trickery as all-white primaries. One hundred years ago, "separate but equal" was the legally accepted rule, and "separate and unequal" was the reality - in education (from grade school through professional education); in transportation (interstate and intrastate); in employment (public and private); in public accommodations; in healthcare in every aspect of our lives.

I will not bore you with more details; I am sure you take the point. Our legal, political, and social system has changed dramatically since 1906 . We can only begin to imagine how our legal, political, and social system will change in the next one hundred years; but we can and must help to shape those changes by advancing a discourse of human rights.

We, as lawyers, have great skills of advocacy and persuasion and the ability to compel people to pay attention to us. [Recalcitrant, haughty officials always are astonished that they have to respond to accusations made by gadflies, whether those accusations are made in the public discourse or in court.] We, as advocates for poor and oppressed people, have the power to advance the recognition and protection of fundamental human rights in the United States. We have that power, and we also have that duty. ${ }^{10}$

9. See Roisman, The Lawyer as Abolitionist, supra note 3.

10. Universal Declaration of Human Rights, G.A. Res. 217A, at 71, U.N. GAOR, 3d Sess., 1st plen. mtg., U.N. Doc A/810 (Dec. 12, 1948) art. 29(1) [hereinafter UDHR]. The UDHR provides that "[e]veryone has duties to the community in which alone the free and full development of his personality is possible." As Nobel Laureate John Polanyi has written, this "refers to the individual's obligation to act in support of those rights. The time has come to underscore the fact that our and others' rights are contingent on our willingness to assert and defend them." UDHR: FIFTY YEARS AND BEYOND, supra note 1, at xii. 
The use of human rights discourse is much more advanced in South Africa, Europe, and other parts of the world than it is in the United States, but it seems to me inevitable that the U.S. will move forward from its current backward status and submit to enforceable legal protection of human rights, as other countries already have. Because this program involves legal standards, it's peculiarly within the province of us as legal advocates - although I do want to emphasize, as this entire conference testifies, that we need to do our persuasive work in the media and with the public in order to make legislators, executives, and judges ready to accept and enforce these principles.

In the brief time I have, I want to explain some of the reasons why I am positive that the time is ripe for us to be using human rights law and then outline some of the riches available in human rights jurisprudence.

\section{WHY THIS ISN'T JUST "PIE IN THE SKY"}

[As legal services/legal aid lawyers, of course it is part of our job to know what courts are holding now and what they are entertaining as bases for decision. But it also is a crucial part of our job to know what courts ought to be holding, and what they ought to be entertaining as bases for decision. And that means that we ought, persistently, to be presenting to state and federal courts the standards established in international law and applied in countries more humane than the United States, so that the courts of the United States may be able to catch up to the rest of the civilized world.]

We should be using international and foreign human rights law, even if domestic courts were now totally resistant to consideration of such doctrine. But the fact is that domestic courts have been considering such legal principles. Indeed, as I will explain in a bit more detail in a minute, a majority of the Supreme Court - a majority of the current, John Roberts, Supreme Court has been using international and foreign human rights law in its decisions.

The Rehnquist Court moved gradually to using international and foreign human rights standards in its opinions. To cite only quite recent cases, in 2003, in Lawrence v. Texas, Justice Kennedy, writing for a five-member majority of the Court, referred to a decision of the European Court of Human Rights, citing an amicus brief filed on behalf of Mary Robinson, former U.N. High Commissioner for Refugees. ${ }^{11}$

Lawrence v. Texas, of course, was the case that overruled Bowers v. Hardwick. ${ }^{12}$ In his concurring opinion in Bowers v. Hardwick, Chief Justice Burger had said that homosexual conduct had "been subject to state

11. Lawrence v. Texas, 539 U.S. 558, 576-77 (2003); see also KENת YOSHINO, COVERING: THE HIDDEN ASSAULT ON OUR CIVIL RIGHTS 188 (2006) (discussing preparation of this brief by "a team centered at Yale Law School" who "argued that decisions by international tribunals and courts in other Western democracies had recognized the fundamentality of the right to adult consensual sexual intimacy.").

12. Bowers v. Hardwick, 478 U.S. 186 (1986). 
intervention throughout the history of western civilization. Condemnation of those practices is firmly rooted in Judeao-Christian moral and ethical standards." ${ }^{13}$ The Lawrence majority responded to Chief Justice Burger's statement by referencing the European Court of Human Rights decision and noting that "other nations, too, have taken action consistent with an affirmation of the protected right of homosexual adults to engage in intimate, consensual conduct." 14 The Lawrence court concluded that "the right the petitioners seek in this case has been accepted as an integral part of human freedom in many other countries." 15

In his 2003 speech to the American Society of International Law, Justice Breyer explained why he - and Justices O'Connor, Ginsburg, Stevens, and Souter - have found foreign or international law pertinent. ${ }^{16}$ After describing "five different ways in which foreign or international law has a growing impact on" the work of the Supreme Court, Justice Breyer urged lawyers to present such arguments. He said:

Neither I nor my law clerks can easily find relevant comparative material on our own. The lawyers must do the basic work, finding, analyzing, and referring us to, that material. I know there is a chicken and egg problem. The lawyers will do so only if they believe the courts are receptive. By now, however, it should be clear that the chicken has broken out of the egg. The demand is there. ${ }^{17}$

13. Id. at 196 (Burger, C.J., concurring).

14. Lawrence, 539 U.S. at 576; see also Jeffrey Toobin, Swing Shift: How Anthony Kennedy's Passion for Foreign Law Could Change the Supreme Court, THE NEW YORKER, Sept. 12, 2005, at 48 (quoting Justice Kennedy as saying:

$[w]$ hen Bowers was being argued, the European Court of Human Rights had just decided Dudgeon v. United Kingdom, which went exactly the way the defendant wanted our court to go .... Y Yet the lawyers didn't even cite it in their briefs ... . Today, no lawyer would think of not telling us how courts around the world have approached the same question.

Id.)

15. Lawrence, 539 U.S. at 577.

16. Stephen Breyer, The Supreme Court and the New International Law, Address at the Ninety-Seventh Annual Meeting of the American Society of International Law, Washington, D.C. (Apr. 4, 2003), available at www.supremecourtus.gov/publicinfo/speeches/sp_04-0403.html; see also Ruth Bader Ginsburg \& Deborah Jones Merritt, Affirmative Action: An International Human Rights Dialogue, 21 CARDozo L. Rev. 253 (1999); Maria Foscarinis, Brad Paul, Bruce Porter, \& Andrew Scherer, The Human Right to Housing: Making the Case in U.S. Advocacy, 38 CLEARINGHOUSE Rev. 97 (July-Aug. 2004).

17. Breyer, supra note 16, at 4; see also Jeffrey Toobin, supra note 14, at 48 (noting that "[i]n many American courts, including the Supreme Court, foreign nations and international organizations regularly file briefs citing their own laws" and quoting Anne-Marie Slaughter, Dean of the Woodrow Wilson School of Public and International Affairs at Princeton University, as saying " $[t]$ he opinions [of foreign and international courts] are out there, easy to get, and the briefs are being filed. If the Justices didn't cite them, it would be like pretending the 
Justice Breyer urged lawyers and law students to present arguments based on foreign and international legal principles, not only in litigation, but also "among the interested publics, affected groups, specialists, legislatures, and others, who interact through meetings, journal articles, the popular press, legislative hearings," and in the many other ways that he says law is created. ${ }^{18}$

This kind of non-litigation advocacy can be immensely important. In a moment, I will cite one of my favorite examples, but first I want to discuss with you the Supreme Court's 2005 decision in Roper v. Simmons, in which a majority of the Court held that the Constitution bars execution of an offender who was older than fifteen, but younger than eighteen, when he committed the capital crime. ${ }^{19}$ It is important to note that the four dissenters in Roper $v$. Simmons were Chief Justice Rehnquist and Justices O'Connor, Scalia, and Thomas - meaning that the substitutions of Chief Justice Roberts for Chief Justice Rehnquist, and Justice Alito for Justice O'Connor, would make no difference in the result. ${ }^{20}$

The majority opinion, written by Justice Kennedy (and joined by Justices Stevens, Souter, Ginsburg, and Breyer), incorporated, and thereby made more authoritative, language from a 1958 plurality opinion in Trop v. Dulles. Quoting Trop, the Roper court said that to interpret "expansive language in the Constitution, ... we have established the propriety and affirmed the necessity of referring to 'the evolving standards of decency that mark the progress of a maturing society." "21 The Court's holding in Roper was based on its conclusion that a "national consensus against the death penalty for juveniles" had developed within the United States; $; 2$ but the majority went out of its way to discuss how this holding relates to international legal standards and the laws of other nations. ${ }^{23}$ The Court said that, at least since the Trop decision in 1958, "the Court has referred to the laws of other countries and to international

rest of the world didn't exist"); see also id. at $\mathbf{5 0}$ (quoting Justice Kennedy as stating:

[t] ] European courts, in particular the transnational courts, have been somewhat concerned, and some feel demeaned, that we did not cite their decisions with more regularity .... They cite ours all the time. And, basically, they were saying, '[w]hy should we cite yours if you don't cite ours?

Id.).

18. Breyer, supra note 16 , at 4.

19. Roper v. Simmons, 543 U.S. 551, 578-79 (2005).

20. It is also worth noting that Justice $O^{\prime}$ Connor expressly disagreed with the other three dissenters' objections to the use of international and foreign law, as I will discuss after I have outlined the majority opinion. Id.

21. Roper, 543 U.S. at 560-61, (quoting Trop v. Dulles, 356 U.S. 86, 101 (1958)). Justice O'Connor, dissenting in Roper, agreed with Trop' $s$ statement that the Eighth Amendment "must draw its meaning from the evolving standards of decency that mark the progress of a maturing society." Id. at 587, 589 (O’Connor, J., dissenting).

22. Roper, 543 U.S. at 564.

23. It is interesting that in Roper, the State of Missouri, as well as the defendant, used international law as a basis for its argument. The State, urging that there was not a national consensus against capital punishment for juveniles, noted that when the Senate ratified the International Covenant on Civil and Political Rights, "it did so subject to the President's proposed reservation regarding" the prohibition of capital punishment for juveniles. Id. at 567 . 
authorities as instructive for its interpretation of the Eighth Amendment's prohibition of 'cruel and unusual punishments." 24 The Court supported this by citing the plurality decision in Trop ("the civilized nations of the world are in virtual unanimity that statelessness is not to be imposed as punishment for crime"); the 2002 decision in Atkins v. Virginia (recognizing that "within the world community, the imposition of the death penalty for crimes committed by mentally retarded offenders is overwhelmingly disapproved"); ${ }^{25}$ the 1988 plurality opinion in Thompson v. Oklahoma (noting the abolition of the juvenile death penalty "by other nations that share our Anglo-American heritage, and by the leading members of the Western European community"); ${ }^{26}$ the 1982 decision in Enmund v. Florida $;^{27}$ and the 1977 plurality opinion in Coker $v$. Georgia. ${ }^{28}$ The Roper court then referred to the U.N. Convention on the Rights of the Child (ratified by every country but Somalia and the U.S.), the International Covenant on Civil and Political Rights, the American Convention on Human Rights, the African Charter on the Rights and Welfare of the Child, and amicus briefs submitted by the European Union, the Human Rights Committee of the Bar of England and Wales, former U.S. diplomats, and President James Earl Carter, Jr., et al. The Court also referred to the practices of other nations, noting that only seven countries other than the United States had executed juveniles since 1990, and that since then each of the other countries had either abolished or publicly disavowed the practice. ${ }^{29}$ The court gave particular emphasis to the practice in the United Kingdom "in light of the historic ties between our countries and in light of the Eighth Amendment's own origins." ${ }^{30}$

The Roper Court said that "[i]t is proper that we acknowledge the overwhelming weight of international opinion ... [; t]he opinion of the world community, while not controlling our outcome, does provide respected and significant confirmation for our own conclusions." stating that "[i]t does not lessen our fidelity to the Constitution or our pride in its origins to acknowledge that the express affirmation of certain fundamental rights by other nations and peoples simply underscores the centrality of those same rights within our own heritage of freedom. ${ }^{32}$ [Thus, we see that a

24. Id. at 575.

25. Atkins v. Virginia, 536 U.S. 304, 316 n.21 (2002) (citing Trop, 356 U.S. at 102).

26. Thompson v. Oklahoma, 487 U.S. 815, 830 (1988).

27. Enmund v. Florida, 458 U.S. 782, 796-97 (1982).

28. Coker v. Georgia, 433 U.S. 584,596 n. 10 (1977).

29. Roper, 543 U.S. at 577; see also Brief for The Human Rights Committee of the Bar of England and Wales, et al. as Amici Curiae Supporting Respondent, Roper v. Simmons, 543 U.S. 551 (2005) (No. 03-633) 2004 U.S. S. Ct. Briefs LEXIS 432. The amicus brief was submitted by Professor Connie de le Vega. Id.

30. Roper, 543 U.S. at 577.

31. Id. at 578.

32. Id. Justice $\mathrm{O}^{\prime}$ Connor dissented from the majority because she did not agree that a domestic consensus against the juvenile death penalty had evolved. Id. at 604 (O'Connor, J., dissenting). Nevertheless, Justice O'Connor went out of her way to say that she "disagree[s] 
majority of the members of the current, John Roberts, Supreme Court have used international and foreign human rights law in the Court's opinions. Justices Scalia and Thomas and Chief Justice Rehnquist opposed such use, but they have been and continue to command only a minority on the court. Moreover, the new Chief Justice himself has not ruled out the use of such material. At the confirmation hearings for Chief Justice Roberts and Justice Samuel Alito, Senators Kyl, Sessions, and Coburn, in particular, expressed their opposition to the use of international and foreign law and sought to elicit the nominees' views on that subject. While then-Judge Alito said that he did not "think that foreign law is helpful in interpreting the Constitution,"33 then-Judge Roberts was more circumspect. ${ }^{34}$ ]

As I mentioned, Justice Breyer's 1993 speech urged lawyers to make arguments based on international and foreign human rights law, not only in court, but also in other forums. An illuminating instance of the non-litigation use of international human rights law occurred in connection with one of the most important civil rights / human rights decisions of the U.S. Supreme Court, Shelley v. Kraemer, and its companion, Hurd v. Hodge, in which the Court barred the judicial enforcement of racially restrictive covenants.

The decisions in Shelley and Hurd were a dramatic, indeed radical, change in the Court's jurisprudence, for the Court had repeatedly, and recently, refused to interfere with the enforcement of such covenants. Scholars have worked hard over the decades to understand why the Court made such a radical

with Justice Scalia's contention . . . that foreign and international law have no place in our Eighth Amendment jurisprudence. Over the course of nearly half a century, [t]he Court has consistently referred to foreign and international law as relevant to its assessment of evolving standards of decency." Id. (citing Atkins, Thompson, Enmund, Coker, and Trop). Justice O'Connor also wrote that "this inquiry reflects the special character of the Eighth Amendment, which ... draws its meaning directly from the maturing values of civilized society." Id. at 60405. Recognizing the distinctiveness of U.S. law in some situations, as urged by Justice Scalia, she stated:

this nation's evolving understanding of human dignity certainly is neither wholly isolated from, nor inherently at odds with, the values prevailing in other countries. On the contrary, we should not be surprised to find congruence between domestic and international values, especially where the international community has reached clear agreement - expressed in international law or in the domestic laws of individual countries - that a particular form of punishment Id. at 605 .

is inconsistent with fundamental human rights.

33. Confirmation Hearing on the Nomination of Samuel A. Alito, Jr., Before the Senate Committee on the Judiciary, 109th Cong., 2nd Sess. 370, 410, 471, cf. 581 (2005) [hereinafter Alito Hearings] (responding to Senator Leahy: "Most of our common law is an outgrowth of English common law, and I think it helps to understand that background often in analyzing issues that come up.").

34. See Confirmation Hearing on the Nomination of John G. Roberts, Jr., before the Senate Committee on the Judiciary, 109th Cong., 1st Sess. 199-201, 292-293 (2005) [hereinafter Roberts Hearings]; see also Alito Hearings, supra note 33, at 471 (Senator Cobum asking Judge Alito if the Supreme Court should use foreign law, and stating that he "could not get Judge Roberts to answer [the question] . . . because of the conflict that might occur afterwards ...."). 
change. Everyone agrees that a big part of the explanation is that the U.S. Department of Justice participated in those cases amicus curiae, submitting a brief signed not only by the Solicitor General, but also by the Attomey General, and presenting oral arguments by the Solicitor General himself, Philip Perlman. ${ }^{35}$

Solicitor General Perlman told the Supreme Court that this was "the first instance in which the government had intervened in a case to which it was not a party and in which its sole purpose was the vindication of rights guaranteed by the Fifth and Fourteenth Amendments." ${ }^{36}$ Given that the participation of the United States goes very far to explain why the Court adopted the position urged by DOJ, the burning question then becomes: why did the Department of Justice take this dramatic step? Again, there are many elements to that answer, ${ }^{37}$ but part of the explanation lies in the use of international human

35. Brief for the United States as Amicus Curiae supporting Petitioner-Appellant, Shelley v. Kraemer, 334 U.S. 1 (1947) (Nos. 72, 87, 290, 291), 1947 WL 44159; see Seth P. Waxman, Twins at Birth: Civil Rights and the Role of the Solicitor General, 75 IND. L.J. 1297, 1306 (2000) ("[T]here can be little doubt, in this period of utmost fragility in civil rights litigation, that the cautious Supreme Court would attach great significance to the position - if any - the Tenth Justice [that is, the Solicitor General] might choose to take."); see also CHARLES ABRAMS, ForRIDDEN NEIGHBors: A STUDY OF PREJUDICE IN Housing 220 (1955) ("[W]ithout the government's intervention it is doubtful that the Supreme Court would have accepted review" of the two cases.). Abrams misspeaks here, for the Supreme Court accepted review before the government expressed its support for the petitioners. The only amicus in support of the petition was the St. Louis Civil Liberties Committee. Clement E. Vose, Caucasians Only: The SUPREME COURT, THE NAACP AND THE Restrictive Covenant CASES 196 (1959).

36. See MARY L. DudZiaK, COLD W AR Civil RIGHTS: RACE AND THE IMAGE OF AMERICAN DEMOCRACY 91, 277 (2000) (paraphrasing Solicitor General Philip Perlman's oral argument to the Supreme Court).

37. See, e.g., VOSE, supra note 35 , at 173 (stating that when the participants at the NAACP planning session in September 1947 agreed it was "important to get government in on" the case, Phineas Indritz, an attorney in the Department of the Interior who had been volunteer co-counsel with Charles Hamilton Houston in the Hurd case, advised "it would be a good idea for the directors of the various organizations represented to visit the heads of the various departments. There should be a well-coordinated group action to get behind these agencies"); see also Arnold R. Hirsch, Searching for a 'Sound Negro Policy': A Racial Agenda for the Housing Acts of 1949 and 1954, 11 HousING POL'y DEBATE 393, 397 (2000) and Anold R. Hirsch, Choosing Segregation: Federal Housing Policy Between Shelley and Brown, in From TENEMENTS to THE Taylor Homes: In SEARCH OF an URban Housing Policy In TWENTIETH CENTURY AMERICA 211-22 (John F. Bauman, Roger Biles, \& Kristin M. Szylvian, eds., 2000) (describing the work of Dr. Frank S. Horne, an African-American who was the Racial Relations Adviser in the Housing and Home Finance Agency and a special assistant to HHFA administrator Raymond M. Foley); see also Philip Elman, interviewed by Norman Silber, The Solicitor General's Office, Justice Frankfurter, and Civil Rights Litigation, 1946-1960: An Oral History, 100 HARV. L. REV. 817, 818 (1987) (Philip Elman said that he and Phineas Indritz arranged to have Oscar Chapman write to the Attomey General to request an amicus brief in the restrictive covenant cases and that he, Elman, was responsible for the letters that went to the DOJ from the NAACP, the ACLU, the American Jewish Committee, the American Jewish Congress, and other organizations, as well as the State Department); but see Randall Kennedy, $A$ Reply to Philip Elman, 100 HARV. L. REv. 1938, 1940 (1987) ("Elman's memoir is . . a classic example of the treachery of nostalgia. In the end, its combination of factual errors and poor 
rights law in a non-litigation context by the National Association for the Advancement of Colored People (NAACP).

On June 6, 1946, the National Negro Congress (NNC) presented to the United Nations a petition, drafted by Herbert Aptheker, seeking relief for the plight of African-Americans in the United States. ${ }^{38}$ The NNC did not have the organizational capacity or political credibility to pursue its petition effectively. ${ }^{39}$ But the NAACP, which had supported the NNC, then prepared its own, much more extensive, petition to the U.N.

Under the leadership of Dr. W.E.B. Du Bois, on October 23, 1947, the NAACP filed with the United Nations "an appeal to the world," a lengthy, detailed, substantial petition protesting the treatment of African-Americans in the United States. ${ }^{40}$ Reacting to the NAACP's petition to the U.N., Attorney General Tom Clark said, "I was humiliated . . . to realize that in our America there could be the slightest foundation for such a petition." 41 Speaking on October 27, a few days after the NAACP petition had been filed, Attorney General Clark declared that the Justice Department would move " "with as great vigor and force as is permitted under the law where states through negligence, or for whatever reason, fail . . . to protect the life and liberties of the individual.' He also announced the civil rights section of the Justice Department would be enlarged and strengthened." ${ }^{, 42}$ On October 30, 1947, a week after the NAACP had filed its petition with the United Nations, the U.S. Department of Justice announced its decision to file an amicus brief in the restrictive covenant cases in the Supreme Court. ${ }^{43}$

I certainly do not mean to say that the NAACP petition was the cause of the decision to have DOJ participate amicus in Shelley and Hurd, but I do think it is reasonable to believe that the NAACP petition had some impact on that decision. This is particularly likely in view of the fact that "only three months earlier, the NAACP had tried to enlist Justice Department support in a series of restrictive covenant cases, but neither Attorney General Tom Clark nor Solicitor General Philip Perlman was interested."44 (Attorney General Clark,

judgments makes it unreliable legal history and bad reminiscence"); id.at 1948 (referring to "Elman's ... revisionism.").

38. ANDERSON, supra note 5 , at 80-81.

39. Id., at 81-92.

40. See David Levering Lewis, W.E.B. DuBois: The Fight For Equality and THE AMERICAN CENTURY, 1919-1963 (2000) at 528-29; see also WILIAM C. BERMAN, THE POLITICS OF CIVIL RIGHTS IN THE TRUMAN ADMINISTRATION 65-66 (1970) (giving the date as Oct. 23); see also DUDZIAK, supra note 36, at 44 (The petition "created an international sensation.").

41. DUDZIAK, supra note 36 , at 45 .

42. BERMAN, supra note 40 , at 66 .

43. VoSE, supra note 35, at 169, 173; compare RICHARD KLUGER, SIMPLE JUSTICE: THE HISTORY OF BROWN V. BOARD OF EDUCATION AND BLACK AMERICA's STRUGGLE FOR EQUALITY 253 (2004) ("The week after the publication of the Committee's report, the Department decided to intervene as amicus curiae.").

44. Cornell W. Clayton, The Polttics of Justice: The Attorney General and the MAKING OF LEGAL POLICY 128 (1992). 
from Texas, certainly was not then noted as a civil libertarian. ${ }^{45}$ Some scholars have suggested that the reason for the change of heart was the administration's interest in securing the votes of African-Americans in the North, ${ }^{46}$ but it is certainly reasonable to give to the NAACP (and the NNC) petitions credit for making the restrictive covenant issue even more salient for the administration and the voters it was trying to woo.

Moreover, it is pertinent that the brief filed by DOJ used international and foreign standards. The Justice Department's brief relied on, inter alia, provisions of the Charter of the United Nations (which had been approved by the Senate as a treaty); a declaration of the U.N. General Assembly; a resolution adopted by the Eighth International Conference of American States at Lima, Peru, in 1938; the "Economic Charter of the Americas," adopted by the InterAmerican Conference on Problems of War and Peace in 1945, which said that "the fundamental economic aspiration of the peoples of the Americas, in common with peoples everywhere, is to be able to exercise effectively their natural right to live decently . . ."; another resolution adopted by the InterAmerican Conference, and a statement made by the U.S. Secretary of State at the conclusion of the conference in which he said that "we have rededicated ourselves ... to American principles of humanity and to raising the standards of living of our peoples; so that all men and women in these republics may live decently in peace, in liberty, and in security."

The Department of Justice also relied on a decision of the Ontario High Court in Canada and made the point that it had "found no English or Australian cases on the point." 47 In arguing against the covenants because they contravened a "policy of free alienability" of real property, the Department noted that "a few early British cases . . looked the other way, but they felt the great weight of judicial and professional disapproval." ${ }^{48}$ The DOJ argued that

45. VosE, supra note 35 , at 172 ("Clark ... had no name in the civil-rights field ... . Also, like Clark, Solicitor General Perlman was without any public record as a supporter of civil rights.").

46. See e.g., Clayton, supra note 44, at 127-28; ElMAN, supra note 37, at 817-18; DUDZIAK, supra note 36, at 25, 86; BERMAN, supra note 40, at 74.

47. DudzIAK, supra note 36, at 47; see TOM C. ClARK \& PHILIP B. PERLMAN, PREJUdice AND PROPERTY: AN Historic BRIEF AgAINST RACIAL COVENANTS 21, 92 n.62, $101 \mathrm{n} .11,103$ n.28 (1948). The brief also noted an apparently contradictory Ontario decision. Id. at 92 n.62.

48. Id. at 105-06 CLARK \& PERLMAN, PREJUDICE AND PROPERTY, supra note 47, at 76-77, $99 \mathrm{n} .7$; see also id. at $92 \mathrm{n} .63$ (discussing " $\mathrm{t}]$ he rather unclear state of the English common-law rule on restraints on alienation ....") In this connection, it is worth noting that critics of the use of foreign law complain, inter alia, that using foreign law allows judges to "pick and choose among those foreign laws that we liked or didn't like." Senator Kyl, in Roberts Hearings, supra note 34 , at 199 . Then-Judge Roberts responded:

In foreign law you can find anything you want. If you don't find it in the decisions of France or Italy, it's in the decisions of Somalia or Japan or Indonesia or whatever. As somebody said in another context, looking at foreign law for support is like looking out over a crowd and picking out your friends. You can find them, they're there.

Roberts Hearings, supra note 34, at 201. Chief Justice Roberts may have been referring to a 
these authorities supported the argument that racially restrictive covenants should not be judicially enforceable in the United States. ${ }^{49}$ The Department of Justice may not be using international and foreign law under the direction of Alberto Gonzales and Paul Clement, but it has done so in the past and, I have no doubt, will do so in the future.

[I am not breaking new ground in urging that we use foreign and international law in our domestic arguments, in and out of court. Legal aid lawyers have been raising international human rights claims for decades, and public interest lawyers continue to do so. Connie de la Vega, Andy Scherer, Maria Foscarinis, and other legal services and public interest lawyers have been using and writing about using international human rights law in our advocacy. ${ }^{50}$ Some of our colleagues have been participating in such activities as filing with the U.N. Special Rapporteur on Housing a statement regarding housing segregation in the U.S., prepared for the 2005 North American Consultation on Women and the Right to Housing, and filing a submission on racial segregation and the right to housing before the Inter-American Commission on Human Rights in connection with the Commission's consideration of the situation of the right to adequate housing in the americas. ${ }^{51}$ ]

concurring opinion by Justice Scalia in Conroy v. Aniskoff, 507 U.S. 511 , 519 (1993) (Scalia, J., concurring), which Justice Scalia mentioned in his dissent in Roper, 543 U.S. at 617 (Scalia, J., dissenting). In Conroy, Justice Scalia commented that "Judge Harold Leventhal used to describe the use of legislative history as the equivalent of entering a crowded cocktail party and looking over the heads of the guests for one's friends." Conroy, 507 U.S. at 519. In Roper, Justice Scalia applied this to the use of "scientific and sociological studies." Roper, 543 U.S. at 617. As the Justice Department's reference to foreign law contrary to its position illustrates, responsible advocates and judges will refer to standards that support the position they oppose and then indicate why those standards should not be adopted in the instant case.

49. Clark \& PERLMAN, supra note 47, at 70-73. The Department of Justice again used "treaties and international agreements" in its brief in Henderson v. United States. Brief for the United States, Henderson v. United States, 339 U.S. 816 (1950) (No. 25), 1949 WL 50329, at 62-63 (citing the U.N. Charter and a resolution adopted at the 1945 Inter-American Conference on Problems of War and Peace).

50. See, e.g., Brief for Human Rights Advocates and the University of Minnesota Human Rights Center in Support of Petitioners, as Amici Curiae supporting Petitioner, Grutter v. Bollinger, 539 U.S. 306 (2003) (Nos. 02-241, 02-516), 2003 WL 399226 (submitted by Connie de la Vega); Amici Curiae Brief in Support of Respondent, Roper v. Simmons, supra note 29; Connie de la Vega, Using International Human Rights Law in Legal Services Cases, 22 Clearinghouse Rev. 1242 (1989); Connie de la Vega, Protecting Economic, Social and Cultural Rights, 15 WHITTER L. REV. 471 (1994); Connie de la Vega, Civil Rights During the 1990s: New Treaty Law Could Help Immensely, 65 U. CIN. L. REV. 423 (1997); Foscarinis et al., supra note 16; Martha F. Davis, Human Rights in the Trenches: Using International Human Rights Law in "Everyday" Legal Aid Cases, 41 ClearingHouse ReV. 414 (2007).

51. See Allard K. Lowenstein, International Human Rights Clinic, Yale Law School, on behalf of Poverty and Race Research Action Council, Submission on Racial Segregation and the Right to Housing, for the 122nd Period of Sessions of the Inter-American Commission on Human Rights: Situation of the Right to Adequate Housing in the Americas Hearing (Mar. 8, 2002), available at http://www.ccr-ny.org/v2/legal/govt_misconduct/docs/PPEHR_PPRAC.pdf; see also Brief Statement from Philip Tegeler, Director, Poverty \& Race Research Action Council, Washington, D.C., to The Hon. Miloon Kothari, U.N. Special Rapporteur on Housing on the Issue of Housing Segregation in the United States, prepared for the 2005 North American 
[I am by no means alone in believing that these efforts will be successful. Yale law professor Kenji Yoshino, in his fascinating new book, Covering: The Hidden Assault on our Civil Rights, says that "the Supreme Court's shift toward a more universal register can . . . be seen in its nascent acceptance of human rights" and predicts that "the universal rights of persons will probably be the way the Court will protect difference in the future." $\left.{ }^{, 52}\right]$

\section{WHAT WE HAVE TO USE}

Having, I hope, given you reason to be open to considering the use of foreign and international human rights standards, let me briefly review what those standards are. Their genesis in public discourse in the United States can be dated to President Franklin Roosevelt's 1941 declaration of the four freedoms: freedom of speech and belief and freedom from fear and want. ${ }^{53}$ [These goals were embodied in the Atlantic Charter of August 1941, in which President Roosevelt and British Prime Minister Winston Churchill seemed to "commit . . . the allied powers to improving the quality of life for the world's inhabitants, and promise . . . a peace that would secure for all people the four freedoms, especially freedom from fear and want." ${ }^{\text {, }}$ ]

They were reflected also in the U.N. Charter of 1945 , which provides that "the United Nations shall promote ... universal respect for, and observance of, human rights and fundamental freedoms for all without distinction as to race, sex, language, or religion." 55 The four freedoms then became a "touchstone for the framers of the" Universal Declaration of Human Rights (UDHR), promulgated by the United Nations in $1948 .^{56}$ And the UDHR then was fleshed out in two important international covenants, the International Covenant on Civil and Political Rights (ICCPR) and the International Covenant on

Consultation on Women and the Right to Housing (Sept. 30, 2005); Noah Leavitt, International Human Rights Violations Here in the U.S.: A U.N. Visit to Chicago's Cabrini-Green Housing Project, May 6, 2004, http://writ.news.findlaw.com/leavitt/20040506.html; PPEHRC Travels to Washington DC for Hearing of the OAS, Poor People's Economic Human Rights Campaign, Mar. 2000, http://economichumanrights.org/updates/oashearing.htm; Noah Leavitt, Durban Gone But Not Forgotten: Global Anti-Discrimination Efforts in a Difficult Year, $10 \mathrm{~J}$. OF THE INTERNATIONAL InSTITUTE 1 (2002); Noah Leavitt \& Rafi Rom, Oh, Give Me A Home, AlterNet, Mar. 10, 2005, http://alternet.org/module/printversion/21469; Rabbi Jill Jacobs \& Noah Leavitt, Shelter the Displaced Among Us, SOCIALACTION.COM: AN ONLINE JEWISH RESOURCE FOR REPAIRING THE WORLD, June http://www.socialaction.com/issues/economic_justice/housing_homelessness/SheltertheDisplace d.shtml.

52. Yoshino, supra note 11 , at 188.

53. Franklin D. Roosevelt, U.S. President, State of the Union, Jan. 6, 1941, available in THE PUBLIC PAPERS AND ADDRESSES OF FranKLIN D. RoOSEVELT: 1938-1950, at 672 (Random House 1950) (1938).

54. ANDERSON, supra note 5, at 16 .

55. U.N. Charter art. 55, ch. IX, June 26, 1945, available at http://www.un.org/aboutun/charter.

56. Mary ann Glendon, A World Made New: Eleanor Roosevelt and the UNIVERSAL DECLARATION OF HUMAN RIGHTS 176 (2001); see also UDHR, supra note 10, art. 25. 
Economic, Social and Cultural Rights (ICESCR). ${ }^{57}$ Subsequent conventions have dealt with, inter alia, the elimination of racial discrimination, the elimination of discrimination against women, discrimination in education, and the rights of the child. ${ }^{58}$

Regionally, the Organization of American States adopted the American Declaration of the Rights and Duties of Man in 1948 and the American Convention on Human Rights (ACHR) in 1969. "The ACHR has ... optional protocols dealing with . . . economic, social, and cultural rights." There are additional conventions dealing with, inter alia, violence against women. ${ }^{61}$ The ACHR created the Inter-American Court of Human Rights in $1978 .^{62}$ The "core of international human rights law" is contained in these six instruments: the Charter of the United Nations; the ACHR; and what is called "the International Bill of Human Rights," consisting of the UDHR, the ICESCR, the ICCPR, and the optional protocol to the ICCPR. ${ }^{63}$

International human rights law may be especially useful to us in two respects: its protections against discrimination (which are more expansive than

57. International Covenant on Civil and Political Rights, G.A. Res. 2200A (XXII), U.N. Doc. A/6136 (Mar. 23, 1976), [hereinafter ICCPR] (entered into force March 23, 1976, adopted by the United States Sept. 8, 1992); International Covenant on Economic, Social and Cultural Rights, G.A. Res. 2200A (XXI), U.N. Doc.A/6316 (Jan. 3, 1976) [hereinafter ICESCR] (entered into force July 18, 1978, adopted by United States Oct. 5, 1977); Article 11(1) of the ICESCR also provides "[t]he States Parties will take appropriate steps to ensure the realization of this right ...." See also Committee on Economic, Social, and Cultural Rights, General Comment 1, Reporting by States Parties, 3rd Sess., U.N. Doc. E/1989/22, annex III at 87 (1989), reprinted in Compilation of General Comments and General Recommendations Adopted by Human Rights Treaty Bodies, U.N. Doc. HRI/GEN/1/Rev.6 at 8 (2003) (calling on member states "to realize progressively the full range of economic, social and cultural rights.").

58. Convention on the Elimination of All Forms of Racial Discrimination, G.A. Res. 2106 (XX), U.N. Doc. A/6014 (Dec. 21, 1965) (opened for signature March 7, 1966, entered into force Jan. 4, 1969, adopted by the United States Nov. 20, 1994) [hereinafter CERD]; Convention on the Elimination of All Forms of Discrimination Against Women, G.A. Res. 34/180, U.N. GAOR, 36th Sess., Supp. No. 46, at 193, U.N. Doc. A/RES/34/180 (entered into force Sept. 3, 1981, adopted by the United States July 17, 1986) [hereinafter CEDAW]; Convention Against Discrimination in Education, 49 U.N.T.S. 93 (opened for signature Dec. 14, 1960, entered into force May 22, 1962) [hereinafter after CADE]; Convention on the Rights of the Child, G.A. Res. 44/25, Annex, U.N. GAOR Supp.No. 149 at 167,44th Sess., Supp. No. 49, at.167, U.N. Doc. A/44/49 (opened for signature Nov. 20, 1989, entered into force Sept. 2, 1990, adopted by the United States Feb. 16, 1991) [hereinafter CRC].

59. American Declaration of the Rights and Duties of Man, Approved by the Ninth International Conference of American States, Bogotá, Columbia, 1948, O.A.S. Res. XXX, available at http://cidh.oas.org/Basicos/English/Basic2.American\%20Declaration.htm; American Convention on Human Rights, Adopted at the Inter-American Specialized Conference on Human Rights, San Jose, Costa Rica, November 22, 1969, O.A.S. Treaty Series No. 73 (1990) available at $\mathrm{http}: / / \mathrm{cidh} . o a s . o r g / B a s i c o s / E n g l i s h / B a s i c 3 . A m e r i c a n \% 20$ Convention.htm.

60. de la Vega, Using International Human Rights Law, supra note 50, at 1243.

61. Id. at 1243 n.9.

62. Francisco Forrest Martin et al., INTERnational Human Rights and Humanitarian Law: Treaties, Cases and ANalysis 24 (2006).

63. de la Vega, Using International Human Rights Law, supra note 50, at 1243. 
are those in domestic U.S. law) and its protection of economic, social, and cultural rights. As to the first, Article 2 of the UDHR states "everyone is entitled to all the rights and freedoms set forth in this declaration, without distinction of any kind, such as race, colour [sic], sex, language, religion, political or other opinion, property, birth[,] or other status."64

Article 2 of the ICCPR provides that

each state party to the ... Covenant undertakes to respect and to ensure to all individuals within its territory and subject to its jurisdiction the rights recognized in the present covenant, without distinction of any kind, such as race, colour [sic], sex, language, religion, political or other opinion, national or social origin, property, birth[,] or other status. ${ }^{65}$

The ICCPR also provides that "each state party . . . undertakes to take the necessary steps, in accordance with its constitutional processes . . ., to adopt such legislative or other measures as may be necessary to give effect to the rights recognized in the present covenant." ${ }^{, 66}$ The U.S. has ratified the ICCPR, which has the status of a treaty. ${ }^{67}$ The U.S. made its acceptance of the ICCPR subject to the understanding that such distinctions are permitted "when such distinctions are, at minimum, rationally related to a legitimate government objective." 68 Even with the reservations, however, this is more generous than the prohibitions now included in U.S. domestic law, as it expressly prohibits discrimination based on language, property, and "other status." As to the second, the UDHR states that:

everyone has the right to a standard of living adequate for the health and well-being of himself and of his family, including food, clothing, housing and medical care and necessary social services, and the right to security in the event of unemployment, sickness, disability, widowhood, old age[,] or other lack of livelihood in circumstances beyond his control. ${ }^{69}$

This provision of the UDHR was then fleshed out in the International Covenant on Economic, Social and Cultural Rights, which recognizes "the right of

64. UDHR, supra note 10, art. 2.

65. ICCPR, supra note 57, art. 2; see de la Vega, Civil Rights During the 1990s, supra note 50, at 431-37 (discussing the ICCPR).

66. ICCPR, supra note 57 , art. 2.

67. Id., art. 2(1).

68. U.S. Reservations, Declarations, and Understandings, International Covenant on Civil and Political Rights, 138 CoNG. REC. S4781-01 (daily ed. April 2, 1992) (Understandings II 1). Note, however, that the U.N. Charter art. 55 also prohibits discrimination on the basis of language. As to reservations, understandings, declarations, etc., see de la Vega, Civil Rights During the 1990s, supra note 50, at 452-63.

69. UDHR, supra note 10, art. 25(1). 
everyone to an adequate standard of living . . ., including adequate food, clothing[,] and housing, and to the continuous improvement of living conditions." ${ }^{70}$ [To its shame, the U.S. has not ratified the ICESCR, but it has ratified the Convention on the Elimination of all Forms of Racial Discrimination, which applies to, among other things, "economic, social[,] and cultural rights, including the rights to housing; to public health, medical care, social security and social services; to education and training; and to work, equal pay for equal work, and just and favourable [sic] remuneration."71]

[The international human rights principles can be used not only in litigation, but also with the public, the media, and in administrative and legislative fora. In state and federal courts, the International Human Rights standards can be used in a variety of ways. As Professor Connie de la Vega lays out in her Whittier Law Review article, three of those are direct enforcement of treaties, using these standards as customary international law, and using international principles to interpret federal and state constitutional and statutory provisions. ${ }^{72}$ I would add to that, though this may only be making explicit what is implicit in the interpretive use of international standards, using international standards as a way of establishing what is public policy - which is essentially what DOJ was doing in its amicus briefs in Shelley and Hurd.]

For advocacy in the United States, I think it is particularly important to emphasize that the human rights language in these international documents originated in the United States and that it was the United States that advocated for the international codification. ${ }^{73}$

[To mark the fiftieth anniversary of the UDHR, the United Nations published a collection of essays about human rights. The essays were

70. ICESCR, supra note 57. Article 11(1) also provides that "The States Parties will take appropriate steps to ensure the realization of this right ...."; see also Committee on Economic, Social, and Cultural Rights, supra note 57.

71. CERD, supra note 58, art. 5; see also de la Vega, Civil Rights During the 1990s, supra note 50, at 425-431 (discussing the CERD and its requirement of affirmative action); Foscarinis et al., supra note 16, at 102 (citing Concluding Observations of the Human Rights Committee: United States of America, CCPR/C/79/Add.50; A/50/40 II 291, Oct. 3, 1995) (discussing the U.N. Human Rights Committee's 1995 review of U.S. compliance with the treaty, the Committee expressed concern because

disproportionate numbers of Native Americans, African Americans, Hispanics[,] and single parent families headed by women live below the poverty line and that one in four children under six [lives] in poverty... [and] that poverty and lack of access to education adversely affect persons belonging to these groups in their ability to enjoy rights under the Covenant on the basis of equality. Id.).

72. See de la Vega, Using International Human Rights Law, supra note 50, at 1244; de la Vega, Civil Rights During the 1990s, supra note 50 at 423; see also Foscarinis et al., supra note 16 , at 107-11.

73. See supra note 40; see also Simpson, supra note 6, at 243-247 (discussing the U.S. initiation and pursuit of human rights provisions in international documents while accommodating the U.S.'s interest in "ruling out any meddling with the embarrassing racial discrimination practiced by some states, and with U.S. immigration policies."). 
introduced by brief reflections from four Nobel laureates, one of whom was John Polanyi, a Nobel laureate in chemistry. I would like to close by telling you how he concluded his remarks - and I ask you to remember that he is talking about what scientists should do, and I think this applies even more strongly to us as lawyers. He wrote the following:

In challenging my own NGO, the community of scientists, to a greater degree of awareness and activism, I am heeding a passage in the Universal Declaration which I believe must figure more largely in the half-century to come. I refer to the phrase in Article 29 that, following a long litany of rights, refers to the individual's obligation to act in support of those rights. The time has come to underscore the fact that our and others' rights are contingent on our willingness to assert and defend them. ${ }^{74}$

I repeat, to and for all of us: with respect to the human rights that grew out of the four freedoms enunciated by President Franklin Roosevelt and have been recognized in international law for more than fifty years, "the time has come to underscore the fact that our and others' rights are contingent on our willingness to assert and defend them."]

Thank you very much.

\section{RECOMMENDED READING}

Rachel G. Bratt, Michael E. Stone, \& Chester Hartman, Why a Right to Housing Is Needed and Makes Sense: Editors' Introduction, in A RIGHT TO HouSING: FOUNDATION FOR A NEW SOCIAL AGENDA 1 (Rachel G. Bratt, Michael E. Stone, \& Chester Hartman, eds., 2006).

A RIGHT TO HOUSING: FOUNDATION FOR A NEW SOCIAL AGENDA (Rachel G. Bratt, Michael E. Stone, \& Chester Hartman, eds., 2006)

Connie de la Vega, Civil Rights During the 1990s: New Treaty Law Could Help Immensely, 65 U. CIN. L. REV. 423 (1997).

Connie de la Vega, Protecting Economic, Social and Cultural Rights, 15 WHITTIER L. REV. 471 (1994).

Connie de la Vega, Using International Human Rights Law in Legal Services Cases, 22 Clearinghouse REV. 1242 (1989).

74. John Polanyi, in UDHR: FIFTY YEARS AND BEYOND, supra note 1, at xii. 
Maria Foscarinis, Brad Paul, Bruce Porter, \& Andrew Scherer, The Human Right to Housing: Making the Case in U.S. Advocacy, 38 CLEARINGHOUSE REV. 97 (2004).

Maria Foscarinis, Homelessness and Human Rights: Toward an Integrated Strategy, 19 ST. LouIS U. PUB. L. REV. 327 (2000).

Chester Hartman, The Case for a Right to Housing, 9 HOUS. POL'Y DEBATE 223 (1998), reprinted in A RIGHT TO HOUSING: FOUNDATION FOR A NEW SOCIAL AGENDA 177 (Rachel G. Bratt, Michael E. Stone, \& Chester Hartman, eds., 2006).

National Perspectives on Housing Rights (Scott Leckie, ed., 2003).

Francisco Forrest Martin, Stephen J. Schnably, Richard Wilson, Jonathan Simon, Mark Tushnet, INTERNATIONAL HUMAN RIGHTS AND HUMANITARIAN LAW: TREATIES, CASES, \& ANALYSIS (2006). 